DOI https://doi.org/10.15589/znp2021.4(487).14

УДК 502.17:656.13.071.8

\title{
EVALUATION OF EFFICIENCY OF MANAGEMENT DECISIONS OF INCREASING THE LEVEL OF ENVIRONMENTAL SAFETY OF MOTOR TRANSPORT ENTERPRISE
}

\section{ОЦІНКА ЕФЕКТИВНОСТІ УПРАВЛІНСЬКИХ РІШЕНЬ ЩОДО ПІДВИЩЕННЯ РІВНЯ ЕКОЛОГІЧНОЇ БЕЗПЕКИ АВТОТРАНСПОРТНОГО ПІДПРИЕМСТВА}

\author{
Serhii V. Kolomiiets \\ s.kolomiiets@ntu.edu.ua \\ ORCID: 0000-0001-9825-8904 \\ Anna S. Kolomiiets \\ kolomietsa@fit.knu.ua \\ ORCID: 0000-0003-4252-5975
}

\author{
С. В. Коломієць, \\ канд. техн. наук, доцент
}

А. С. Коломісць,

канд. екон. наук, доцент

National Transport University, Kyiv

Начіональний транспортний університет, м. Київ

Taras Shevchenko National University of Kyiv, Kyiv

Київський національний університет імені Тараса Шевченка, м. Київ

\begin{abstract}
Purpose of the research, approaches were developed to assess the effectiveness of management decisions aimed at improving the environmental safety of the transport company. To assess the level of environmental safety of motor transport enterprises and vehicles serviced by them, the most informative criteria are identified, which can compare a large number of possible schemes for organizing the process of maintenance and repair and fleet options for different purposes in terms of pollution, waste generation and consumables costs. This should take into account the universality of criteria for comparing different schemes of the same type and different types of motor transport enterprises, taking into account the operating conditions of the fleet, as well as to assess their compliance with modern environmental safety requirements.In the course of the research a method of forming an integrated criterion of ecological safety of a motor transport enterprise was formed, which is based on the method of expert assessments of a group of criteria of emissions of harmful substances, waste and consumables. Based on the analysis of the current state of environmental impact from the production activities of the trucking company and research on resource and energy saving and reducing the negative impact on the environment during vehicle operation, to improve environmental safety, several options for changing the basic characteristics of the enterprise. Analysis of the level of environmental safety of the studied enterprise on the basis of the proposed criteria and forecasting their recommended changes during the implementation of all environmental and economic measures of significant environmental and economic effect and increase the level of environmental safety of the enterprise from the proposed measures. Thus, the assessment of the effectiveness of management decisions is aimed at improving the level of environmental safety of the transport enterprise with the help of the developed methodology is a common tool in the enterprise management system.
\end{abstract}

Key words: motor transport enterprises; management; environmental safety; fuel and resource costs; emissions and wastes.

Анотація. Мета дослідження - розробити підходи до оцінки ефективності управлінських рішень, спрямованих на підвищення рівня екологічної безпеки автотранспортного підприємства. Для оцінки рівня екологічної безпеки автотранспортних підприємств, а також транспортних засобів, що обслуговуються ними, виокремлено найбільш інформативні критерії, здатні порівняти велику кількість можливих схем організації процесу технічного обслуговування і ремонту та варіантів парку транспортних засобів різного призначення з точки зору рівня забруднення середовища, утворення відходів і витрат експлуатаційних матеріалів. При цьому має враховуватись універсальність критеріїв для порівняння різних схем як однотипних, так і різнотипних автотранспортних підприємств з урахуванням умов експлуатації парку транспортних засобів, а також для оцінки відповідності їх сучасним вимогам екологічної безпеки. У процесі дослідження сформована методика формування інтегрального критерію екологічної безпеки автотранспортного підприємства, яка грунтується на методі експертних оцінок групи критеріїв викидів шкідливих речовин, відходів та витрат експлуатаційних матеріалів. На основі аналізу сучасного 


\section{ТЕХНОЛОГІЇ ЗАХИСТУ НАВКОЛИШНЬОГО СЕРЕДОВИЩА № 4ロ 2021}

стану впливу на навколишнє середовище від виробничої діяльності автотранспортного підприємства та досліджень щодо ресурсо- і енергозбереження та зменшення негативного впливу на довкілля під час експлуатації транспортних засобів запропоновано декілька варіантів змін базових характеристик діяльності підприємства (з метою підвищення рівня екологічної безпеки). Аналіз рівня екологічної безпеки досліджуваного підприємства на основі запропонованих критеріїв і прогнозування їх зміни під час упровадження всіх рекомендованих заходів свідчить про значний еколого-економічний ефект та підвищення рівня екологічної безпеки підприємства через упровадження запропонованих заходів. Таким чином, оцінка ефективності управлінських рішень, спрямованих на підвищення рівня екологічної безпеки автотранспортного підприємства за допомогою розробленої методики, є дієвим інструментом у загальній системі управління підприємством.

Ключові слова: автотранспортні підприємства; управління; екологічна безпека; витрати палива та ресурсів; викиди; відходи.

\section{ПОСТАНОВКА ЗАВДАННЯ}

Автотранспортний комплекс є одним з основних джерел забруднення навколишнього середовища. На частку автотранспорту припадає близько третини від загального обсягу викидів шкідливих речовин в атмосферу, а у мегаполісах ця величина сягає 85-90\%, що створює проблеми для здоров'я населення та стану довкілля загалом [1].

Рівень екологічної безпеки автотранспортного комплексу загалом та основних його елементів визначається рівнем споживання енергії і ресурсів, забруднення навколишнього середовища викидами та відходами в процесі експлуатації транспортних засобів та відновлення працездатності.

На рівні окремих автотранспортних підприємств на рівень екологічної безпеки транспортних засобів вПливає якість та своєчасність робіт із технічного обслуговування і ремонту, оскільки технічні несправності окремих систем транспортних засобів можуть призводити до значного збільшення витрати палива та викидів шкідливих речовин. До актуальних завдань функціонування автотранспортних підприємств разом із забезпеченням заданого рівня технічного стану транспортних засобів належать моніторинг показників енерго- та ресурсоспоживання, викидів та відходів у технологічних процесах відновлення працездатності транспортних засобів для визначення поточного рівня екологічної безпеки підприємства, постійна реалізація заходів, спрямованих на зниження споживання палива та ресурсів, забруднення навколишнього середовища викидами та відходами.

\section{АНАЛІЗ ОСТАННІХ ДОСЛІДЖЕНЬ І ПУБЛІКАЦІй}

Питанням забруднення навколишнього середовища автомобільним транспортом присвячено велику кількість наукових досліджень. Зокрема, поліпшенню екологічних показників окремих транспортних засобів присвячено дослідження G. Pontikakis [4], V. Khrutba [5] та ін. У роботах В.П. Матейчика [6], V. Bilichenko [2], I. Gritsuk [8] запропоновано методи оцінювання і прогнозування шкідливого впливу експлуатації транспортних засобів та організації процесу їх обслуговування на рівень забруднення навколишнього серед- овища. Питання підвищення ефективності роботи автотранспортного підприємства розкрито в роботах В.М. Мельника [11], В.П. Матейчика [8] та ін.

\section{ВИДІЛЕННЯ НЕ ВИРІШЕНИХ РАНІШЕ ЧАСТИН ЗАГАЛЬНОЇ ПРОБЛЕМИ}

Питання впливу технологічних процесів відновлення працездатності транспортних засобів на рівень екологічної безпеки та ефективності управління автотранспортними підприємствами досліджено ще недостатньо, що зумовлює необхідність виконання цього дослідження та визначає його мету і завдання.

Метою дослідження $\epsilon$ комплексне оцінювання впливу окремих технологічних процесів автотранспортних підприємств та структуру парку транспортних засобів на рівень екологічної безпеки цих підприємств, а також вибору ефективних рішень для іiі підвищення.

\section{МЕТОДИ ДОСЛІДЖЕННЯ}

У роботі використано методи порівняльного аналізу, методи оцінювання і прогнозування рівня екологічної безпеки автотранспортних підприємств, експертні методи формування комплексу окремих, групових та інтегральних критеріїв для оцінювання екологічної безпеки автотранспортних підприємств.

Об'єктом дослідження є технологічні процеси автотранспортних підприємств, які впливають на рівень його екологічної безпеки через використання енергії та ресурсів, забруднення навколишнього середовища шкідливими викидами та відходами.

Предметом дослідження $є$ оцінювання впливу структури парку транспортних засобів та характеристик окремих технологічних процесів автотранспортних підприємств на витрату палива та ресурсів, забруднення навколишнього середовища шкідливими викидами і відходами, визначення рівня екологічної безпеки автотранспортних підприємств.

\section{ОСНОВНИЙ МАТЕРІАЛ}

Рішення щодо вибору особливостей діяльності автотранспортного підприємства (режимів руху транспортних засобів в окремих технологічних циклах, типу транспортних засобів, характеристик технологічних операцій, періодичності проведення основних 
технологічних впливів протягом життєвого циклу) ухвалюється на основі порівняльної оцінки показників різних властивостей системи моніторингу технологічного процесу автотранспортних підприємств.

Для оцінки впливу автотранспортних підприємств на навколишнє середовище, як правило, розглядається не один, а сукупність окремих критеріїв $\left\{K_{i}\right\}$, що утворюють векторні критерії $K=\left\{K_{1}, K_{2}, \ldots, K_{i}\right\}$. Векторні критерії $K$ зводяться до різних групових та інтегральних критеріїв.

Для оцінки рівня екологічної безпеки автотранспортних підприємств, а також транспортних засобів, що обслуговуються ними, необхідні найбільш інформативні критерії, здатні порівняти велику кількість можливих схем організації процесу технічного обслуговування і ремонту та варіантів парку транспортних засобів різного призначення з точки зору рівня забруднення середовища, утворення відходів і витрат експлуатаційних матеріалів. При цьому ці критерії повинні бути універсальними для порівняння різних схем як однотипних, так і різнотипних автотранспортних підприємств (з урахуванням умов експлуатації парку транспортних засобів), а також для оцінки їх відповідності сучасним вимогам екологічної безпеки [1].

Цей підхід взято для вибору того чи іншого варіанта організації виробничого процесу підприємства чи складу парку транспортних засобів у визначених умовах, кожна $з$ яких характеризується певною сукупністю значень показників.

Екологічний вплив окремих технологічних процесів етапу відновлення працездатності транспортних засобів полягає у використанні експлуатаційних матеріалів, нафтопродуктів, природного газу, атмосферного повітря, що супроводжується негативними процесами [2-4]: забрудненням атмосфери; забрудненням води; забрудненням земель і грунтів; шумовими, електромагнітними та вібраційними впливами; виділенням в атмосферу неприємних запахів; викидом токсичних відходів; тепловим забрудненням.

Вплив транспортних засобів на довкілля виявляється під час руху транспортних засобів, під час технічного обслуговування, за умов функціонування інфраструктури, яка забезпечує його дію.

Таким чином, витрати ресурсів, викиди шкідливих речовин та утворених відходів є основними елементами шкідливого впливу автотранспортних підприємств на навколишнє середовище. Оскільки екологічні впливи окремих технологічних процесів етапу відновлення працездатності транспортних засобів є різними та численними, то виникає необхідність визначити найбільш суттєві екологічні аспекти окремих технологічних процесів автотранспортних підприємств.

Під час аналізу суттєвих екологічних аспектів окремих технологічних процесів технічного обслуговування і ремонту транспортних засобів та літературних джерел визначено десять окремих критеріїв оцінювання шкідливого впливу стаціонарних і пересувних джерел автотранспортних підприємств, об'єднаних за показниками витрат ресурсів, викидів і відходів (рис. 1).

Наприклад, окремі критерії витрат енергоресурсів, викидів шкідливих речовин та утворення відходів зведені до відповідних групових критеріїв $K_{B E}, K_{B \amalg}, K_{B B}$ :

$$
\begin{aligned}
K_{B E} & =\sum_{i=1}^{3} \beta_{i} \cdot \frac{E_{i}}{E_{i \sigma .}} \\
K_{B \amalg I} & =\sum_{i=1}^{4} \delta_{i} \cdot \frac{C_{i}}{C_{i \sigma .}} \\
K_{B B} & =\sum_{i=1}^{7} \gamma_{i} \cdot \frac{B_{i}}{B_{i \sigma}}
\end{aligned}
$$

де $E_{i}, E_{i \sigma}-$ значення окремих $i$-х критеріїв витрат енергії і ресурсів досліджуваного автотранспортного підприємства та їх бажаний рівень;
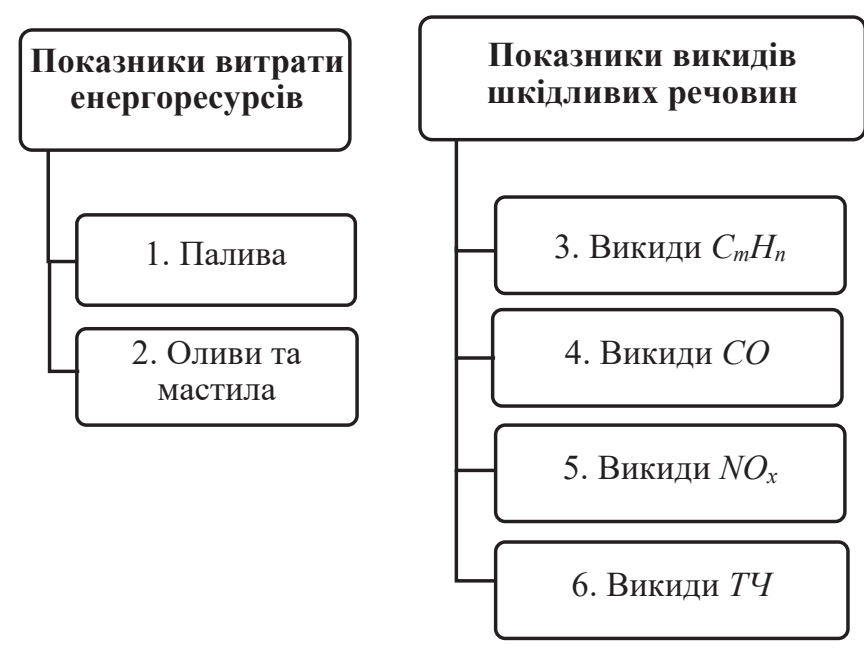

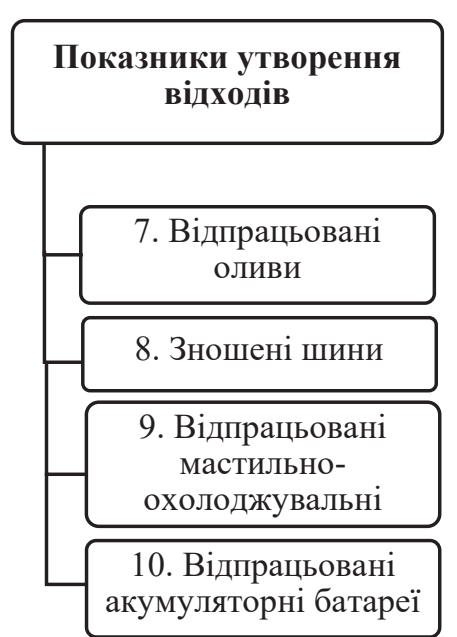

Рис. 1. Критерії оцінювання шкідливого впливу автотранспортних підприємств 


\section{ТЕХНОЛОГІЇ ЗАХИСТУ НАВКОЛИШНЬОГО СЕРЕДОВИЩА № 4- 2021}

$C_{i}, C_{i \sigma}-$ значення окремих $i$-х критеріїв викидів шкідливих речовин досліджуваного автотранспортного підприємства та їх бажаний рівень;

$B_{i}, B_{i \sigma}-$ значення окремих $i$-х критеріїв відходів досліджуваного автотранспортного підприємства та їх бажаний рівень;

$\beta_{i}, \delta_{i}, \gamma_{i}$-вагові коефіцієнти окремих видів витрат, викидів, відходів відповідно $\left(\sum \beta_{i}=1 ; \sum \delta_{i}=1 ; \sum \gamma_{i}=1\right)$.

На основі групових критеріїв витрат енергоресурсів КВЕ, викидів шкідливих речовин КВШ та утворення відходів КВВ сформовано інтегральний критерій екологічної безпеки автотранспортних підприємств, що має вигляд:

$$
K_{E B}=\alpha_{1} \cdot K_{B E}+\alpha_{2} \cdot K_{B U}+\alpha_{3} \cdot K_{B B}
$$

де $\alpha_{1}, \alpha_{2}, \alpha_{3}$ - вагові коефіцієнти складників екологічної безпеки автотранспортних підприємств ( $\left.\sum \alpha_{i}=1\right)$.

Значення вагових коефіцієнтів групових та інтегрального критеріїв екологічної безпеки автотранспортних підприємств визначались методом експертних оцінок з урахуванням досліджень та оцінок інших авторів, технічних характеристик транспортних засобів та технологічного процесу підприємства.

За величиною, зворотною до інтегрального критерію, сформовано одновимірну цільову функцію для оцінювання рівня екологічної безпеки автотранспортних підприємств:

$$
R_{E S}=\frac{1}{K_{E S}} \Rightarrow 1
$$

На основі різних варіантів ситуаційних досліджень та $з$ урахуванням перевищення санітарно-гігієнічних норм запропоновано значення ступенів рівня екологічної безпеки, які дозволяють визначати зони безпечного функціонування технологічного процесу автотранспортних підприємств.
Використовуючи методику оцінки рівня екологічної безпеки автотранспортних підприємств [7] та статистичну інформацію Автобусного парку № 2 КП «Київпастранс», наведену вище, розраховано значення окремих критеріїв екологічної безпеки Автобусного парку № 2 КП «Київпастранс» за 2017-2020 р. (табл. 1).

Таблиця 1. Значення окремих та інтегрального критеріїв екологічної безпеки для АП № 2 КП

\begin{tabular}{|c|c|c|c|c|}
\hline Коефіціснт & 2017 & 2018 & 2019 & 2020 \\
\hline \multicolumn{5}{|c|}{ Показники витрати енергоресурсів } \\
\hline 1. Витрати палива & 0,49 & 0,49 & 0,65 & 0,67 \\
\hline 2. Витрати оливи та мастил & 0,51 & 0,50 & 0,68 & 0,68 \\
\hline \multicolumn{5}{|c|}{ Показники викидів шкідливих речовин } \\
\hline 3. Викиди $C_{m} H_{n}$ & 0,39 & 0,39 & 0,45 & 0,46 \\
\hline 4. Викиди $C O$ & 0,40 & 0,40 & 0,49 & 0,51 \\
\hline 5. Викиди $N O x$ & 0,33 & 0,33 & 0,42 & 0,44 \\
\hline 6. Викиди ТЧ & 0,31 & 0,31 & 0,39 & 0,41 \\
\hline \multicolumn{5}{|c|}{ Показники утворення відходів } \\
\hline 7. Відпрацьовані оливи & 0,40 & 0,40 & 0,45 & 0,46 \\
\hline 8. Зношені шини & 0,55 & 0,55 & 0,57 & 0,58 \\
\hline 9. Відпрацьовані МОР & 0,48 & 0,48 & 0,52 & 0,53 \\
\hline $\begin{array}{l}\text { 10. Відпрацьовані } \\
\text { акумуляторні батареї }\end{array}$ & 0,42 & 0,42 & 0,44 & 0,45 \\
\hline Інтегральний показник & 0,445 & 0,444 & 0,527 & 0,541 \\
\hline
\end{tabular}
«Київпастранс» за 2017-2020 р.

На основі аналізу сучасного стану впливу на навколишнє середовище від виробничої діяльності Автобусного парку № 2 КП «Київпастранс» та досліджень щодо ресурсо- і енергозбереження та зменшення негативного впливу на довкілля під час експлуатації транспортних засобів [8-10] запропоновано чоти-

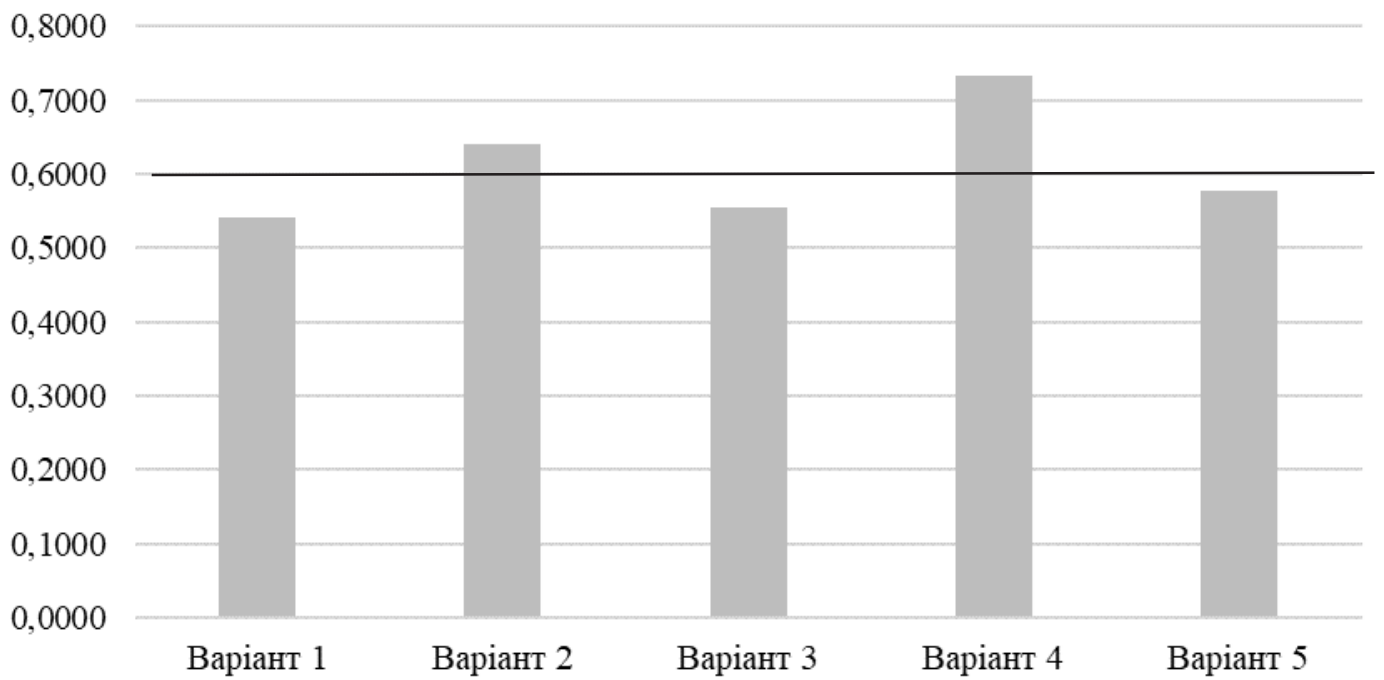

Рис. 2. Порівняльна оцінка рівня екологічної безпеки за різних варіантів організації виробничої діяльності 
ри варіанти змін базових характеристик діяльності підприємства (з метою підвищення рівня екологічної безпеки):

- 1 - базовий варіант без урахування будь-яких змін (для порівняння);

- 2 - використання системи теплової підготовки двигуна транспортного засобу і каталітичного нейтралізатора;

- 3 - підвищення швидкості технологічного руху територією Автобусного парку № 2 КП «Київпастранс» без зміни схеми руху технологічних потоків;

- 4 - заміна всього парку АП № 2 на транспортні засоби екологічного класу СВРО-5 за умов збереження пасажиромісткості та кількості транспортних засобів;

- 5 - удосконалення схеми руху технологічних потоків автотранспорту територією Автобусного парку № 2 КП «Київпастранс».

Використовуючи методику оцінки рівня екологічної безпеки автотранспортних підприємств, наведену вище, та запропоновані варіанти підвищення рівня екологічної безпеки Автобусного парку № 2 КП «Київпастранс», вказані раніше, розраховано значення окремих критеріїв екологічної безпеки Автобусного парку № 2 КП «Київпастранс».

Аналіз рівня екологічної безпеки Автобусного парку № 2 КП «Київпастранс» за інтегральним критерієм і прогнозування його під час упровадження всіх рекомендованих заходів свідчить про значний еколого-економічний ефект та підвищення рівня екологічної безпеки підприємства від упровадження запропонованих заходів (рис. 2).

Проаналізувавши дані 3 рис. 2, можна зробити висновок, що наразі рівень екологічної безпеки Авто- бусного парку № 2 КП «Київпастранс» відповідає рівню середньої безпечності (відповідно до табл. 1), однак за умов упровадження варіантів 2 та 4 рівень екологічної безпеки підприємства підвищиться до безпечного.

\section{ВИСНОВКИ}

Таким чином, удосконалено комплекс критеріїв оцінювання екологічної безпеки автотранспортних підприємств, який відрізняється від дійсних ступенем диференціації оцінювання окремих стаціонарних i пересувних джерел шкідливого впливу підприємства, об'єднаних у групи за чинниками витрат ресурсів, викидів та відходів та інтеграцією всіх шкідливих чинників у єдину функцію мети, яка визначає рівень екологічної безпеки автотранспортних підприємств.

Розроблено комплекс критеріїв оцінювання екологічної безпеки автотранспортних підприємств, який складається 3 десяти окремих критеріїв оцінювання стаціонарних і пересувних джерел шкідливого впливу підприємства, визначених за результатами аналізу суттєвих екологічних аспектів окремих технологічних процесів технічного обслуговування і ремонту транспортних засобів та об'єднаних у групи за чинниками витрат ресурсів, викидів і відходів та інтегральних критеріїв, що формує єдину функцію мети, яка визначає рівень екологічної безпеки автотранспортних підприємств.

Використовуючи вищенаведену методику оцінки рівня екологічної безпеки автотранспортних підприємств, запропоновано варіанти підвищення рівня екологічної безпеки Автобусного парку № 2 КП «Київпастранс», проведено оцінку ефективності управлінських рішень, спрямованих на підвищення рівня екологічної безпеки автотранспортного підприємства.

\section{REFERENCES}

[1] Kolomiiets, S. (2017). Metodyka formuvannya intehral'noho kryteriyu ekolohichnoyi bezpeky av-totransportnoho pidpryyemstva [Methods of forming an integrated criterion of ecological safety of a motor transport enterprise]: Center for Educational Literature. [in Ukrainian]

[2] Bilichenko, V. (2014) Research of influence of specialization level of permanent repair posts on efficiency of autoservice enterprises functioning. Bulletin of polytechnic institute of Iasi. Tomul LX (LXIV). Fasc. 2. - pp. 45-58.

[3] Borshchevsky, O. (2012). Deyaki pytannya dotrymannya ekolohichnosti transportnykh zasobiv katehoriy M, N u sferi tekhnichnoyi ekspluatatsiyi [Some issues of compliance with the environmental friendliness of vehicles of categories M, N in the field of technical operation]. Naukovo-vyrobnychyy zhurnal, no. 3 (227), pp. 14-19.

[4] Pontikakis G. (2001). Mathematical modelling of catalytic exhaust systems for EURO-3 and EURO-4 emissions standards. Proc. Instn. Mech. Engrs. - Part D. pp. 1005-1015.

[5] Khrutba, V. et al. (2019). Peculiarities of Implementation of the Environmental Management System of Motor Transport Enterprises on the Urban Territories. Journal of Environmental Management and Tourism, [S.1.], v. 10, no. 5, pp. 1094-1104. ISSN 2068-7729.

[6] Mateichyk, V., Gorid'ko, N, Kolomiiets, S. (2017). Developing operating procedures of environmental management system at a motor transport enterprise. Systemy i środki tranaportu samochodowego. Efektywność i bezpieczeństwo. Wybrane zagadnienia. Monografia nr 11. Seria: Transport. Rzeszow. pp. 57-62.

[7] Kolomiiets, S., Kolomiiets, A. (2021). Integral Criterion of Environmental Safety as an Indicator of the Effectiveness of a Motor Transport Enterprise Management. In: Lecture Notes in Computational Intelligence and Decision Making. Advances in Intelligent Systems and Computing, vol 1246. Springer, Cham. https://doi.org/10.1007/978-3-030-54215-3 22

[8] Gritsuk, I. (2018). Reducing Harmful Emissions of the Vehicular Engine by Rapid After-Start Heating of the Catalytic Converter Using Thermal Accumulator. SAE Technical Paper 2018-01-0784. p. 12. https://doi:10.4271/2018-01-0784. 
[9] Kontseptsiya rozvytku transportno-dorozhn'oho kompleksu Ukrayiny na seredn'ostrokovyy period ta do 2020 roku (2001). [The concept of development of the transport and road complex of Ukraine for the medium term and until 2020]. Ministerstvo transportu Ukrayiny. Proekt. Avtoprofy. pp. 14-18.

[10] Melnyk, V., Wojciechowska, T. (2012). Zakhody pidvyshchennya ekolohichnoyi bezpeky avtotransportnykh pidpryyemstv [Measures to improve the environmental safety of motor transport enterprises]. Kremenchuk : KDPU. [in Ukrainian]

\section{СПИСОК ВИКОРИСТАНОЇ ЛІТЕРАТУРИ}

[1] Коломієць С., Бойченко С., Лейда К., Матейчик В., Топільницький П. Методика формування інтегрального критерію екологічної безпеки автотранспортного підприємства : монографія. Проблеми хіммотології. Теорія та практика раціонального використання традиційних і альтернативних паливно-мастильних матеріалів. Київ : Центр учбової літератури. 2017.

[2] Bilichenko V. Research of influence of specialization level of permanent repair posts on efficiency of autoservice enterprises functioning. Bulletin of polytechnic institute of Iasi. Tomul LX (LXIV). Fasc. 2. 2014. pp. 45-58.

[3] Борщевський O.O. Деякі питання дотримання екологічності транспортних засобів категорій M, N у сфері технічної експлуатації. Науково-виробничий журнал. № 3 (227). 2012. С. 14-19.

[4] Pontikakis G. Mathematical modelling of catalytic exhaust systems for EURO-3 and EURO-4 emissions standards. Proc. Instn. Mech. Engrs. Part D. 2001. pp. 1005-1015.

[5] Khrutba V. et al. Peculiarities of Implementation of the Environmental Management System of Motor Transport Enterprises on the Urban Territories. Journal of Environmental Management and Tourism, [S.1.], v. 10, no. 5, 2019. pp. 1094-1104. ISSN 2068-7729.

[6] Mateichyk V., Gorid'ko N, Kolomiiets S. Developing operating procedures of environmental management system at a motor transport enterprise. Systemy i środki tranaportu samochodowego. Efektywność i bezpieczeństwo. Wybrane zagadnienia. Monografia nr 11. Seria : Transport. Rzeszow. 2017. pp. 57-62.

[7] Kolomiiets S., Kolomiiets A. Integral Criterion of Environmental Safety as an Indicator of the Effectiveness of a Motor Transport Enterprise Management. In: Lecture Notes in Computational Intelligence and Decision Making. Advances in Intelligent Systems and Computing, vol 1246. Springer, 2021. Cham. URL: https://doi.org/10.1007/978-3-030-54215-3_22

[8] Gritsuk I. Reducing Harmful Emissions of the Vehicular Engine by Rapid After-Start Heating of the Catalytic Converter Using Thermal Accumulator. SAE Technical Paper 2018-01-0784. 2018. p. 12. URL: https://doi:10.4271/2018-01-0784.

[9] Концепція розвитку транспортно-дорожнього комплексу України на середньостроковий період та до 2020 року. (2001). Міністерство транспорту України. Проєкт. Автопрофи. С. 14-18.

[10] Мельник В.М., Войцехівська Т.Й. Заходи підвищення екологічної безпеки автотранспортних підприємств. Екологічна безпека. Кременчук : КДПУ. 2012. № 1/2012 (13). С. 18-21.

(C) Коломієць С. В., Коломієць А. С. Дата надходження статті до редакції: 03.12.2021 Дата затвердження статті до друку: 16.12.2021 